\title{
Policy, Perceptions and Practice: A Study of Educational Leadership and Their Balancing of Expectations and Interests at Micro-Level
}

\author{
Bjørn Stensaker, Nicoline Frølich, Per Olaf Aamodt
}

Accepted for publication in Higher Education Policy, 7 September 2018

\begin{abstract}
As international and domestic policy initiatives continue to sweep over higher education, it is of utmost importance to study how those responsible for the implementation of the many initiatives taken perceive and respond to the many expectations about change and renewal. Through three different analytical perspectives - a managerial, a disciplinary, and a stakeholder perspective - the current article offers insights into how educational leaders responsible for the management of study programs at micro level interpret external expectations and how they prioritise between them. Based on data derived from a representative sample of Norwegian educational leaders, the current article finds - somewhat surprisingly - that the managerial perspective is less relevant for understanding the sensemaking of educational leaders and how they prioritize between different tasks in their daily work. Disciplinary and the stakeholder perspectives are in this respect more relevant for explaining the practices related to program management. The study provides indications of a (continued) gap between macro-level policy-making and its implementation at micro-level. In the conclusion, the findings are reflected upon and implications for policy and practice are outlined.
\end{abstract}

\section{Introduction}

Following the call to reform higher education throughout Europe, many European countries have in recent decades set out to change their higher education systems, including the funding system, governance approaches, and educational offerings (Kehm et al, 2009). Following these changes it is well documented that, as part of the Bologna Process, the bachelor-master structure, the introduction of the ECTS credit system, and national quality assurance systems have been implemented in the majority of European countries (Vukasovic et al, 2015). However, while European policy initiatives and domestic reforms indeed have put their mark on the higher education sector, there is also considerable evidence that structural changes at systems level may not always have the greatest of impact at micro-level (Henkel, 2000; Musselin, 2005; Kehm et al, 2010; De Boer et al, 2017). 
In more recent years, European and national reform ideas in higher education have increasingly underlined student learning as a key objective, and attempted to stimulate change through the introduction of a European Qualification Framework, through more studentcentred emphasis in the European Standards and Guidelines (ESG) (Elken, 2016), and through more political attention directed at increasing student engagement in the learning process following insights from research on teaching and learning (Biggs and Tang, 2011). Through emphasizing the formulation of specific learning outcomes at study programme level it can be argued that we are witnessing a shift in political focus away from structure, governance and organization to more emphasis on the content of the educational offerings, not least addressing issues such as relevance and employability (Young, 2013; Caspersen et al, 2017).

Compared to earlier reform attempts where certain structural `reform templates ' have been offered (bachelor-master structure, ECTS, quality assurance standards, etc), the new `quality challenges ' in teaching and learning that needs to be addressed through public reform are relatively open as to what solutions that are viable and relevant (Frølich et al, 2016; Jungblut et al, 2015). The most prominent normative idea promoted in this respect is that 'educational leadership is important and significant for instigating change at study program level Gibbs et al, 2009; Møthe et al, 2015).

By pointing to the importance of `educational leadership`without offering any normative solutions as to how they are supposed to tackle the expectations related to quality enhancement in teaching and learning could be a challenging task for those having a formal responsibility for educational offerings at micro-level. The challenges may be even greater as traditions, cultures and distinct ways of conducting teaching and learning may represent substantial hurdles for educational leaders having ambitions of stimulating change and renewal locally. The current article investigates how these challenges are interpreted and handled at study program/teaching and learning level by asking how educational leaders makes sense and prioritise between different interests in situations characterised by absence of clear normative solutions.

The article is based on data taken from a recent and representative survey targeting educational leaders of study programmes/teaching and learning in a large sample of Norwegian universities and colleges. Norway is an interesting setting for this study with considerable relevance for other countries due to the co-existence of many competing political reform ambitions and ideas that opens for many possible interpretations and forms of implementation at institutional and micro-level. As in many other European countries, higher education institutions in Norway enjoy considerable autonomy, not least concerning how the educational offerings are designed and organized (Bleiklie and Frølich, 2014). However, this autonomy has also been challenged by the establishment of new national quality assurance regimes, accountability measures such as national student surveys, and various reporting schemes (Møthe et al, 2015; Solbrekke and Stensaker, 2016). As in other European countries, this combination of autonomy and external control do create some space for institutional discretion, and a number of higher education institutions have re-organized their internal 
governance structure as an attempt to balance the many expectations directed at them (Frølich et al, 2016).

The current study contributes to the current research agenda by investigating the general frames and conditions affecting leadership at micro-level in more autonomous higher education institutions, and by analysing the practices associated with such leadership in the educational area in particular. As such, the article may add to our knowledge about the problems related to translating policy into practice in higher education.

\section{Perspectives on reform and change of educational offerings}

\section{The blurring international and domestic political agendas}

There are a number of possible factors and perspectives that can be relevant for understanding how educational offerings develop and change (Gibbs et al, 2009), ranging from how specific disciplines evolve over time and their internal social and cognitive knowledge structures (Becher and Trowler, 2001; Young 2013) to more globally inspired political ambitions for higher education development in general (Maassen and Stensaker, 2011).

The emergence of a global reform agenda and increasing international collaboration in higher education, especially within Europe as part of the Bologna Process (Karseth and Sivesind, 2010), should not be underestimated as a driver for continuous change at study programme level in Europe since the early 2000s (Kehm et al, 2009). Although the focus and general attention related to the Bologna Process perhaps has weakened somewhat in recent years (Vukasovic et al, 2015), the policy signals developed through the process are still considered important, not least as inspiration for domestic reform (Neave and Veiga, 2013). As Neave and Veiga (2013) underline, the Bologna Process has been a carrier and a driver of multiple policy ideas and agendas that still play an important role in the European landscape of higher education.

While national needs, characteristics and traditions still play a considerable role in determining domestic policy agendas, internationalization and globalization do impact which policy ideas are considered legitimate (Karseth and Sivesind, 2010). The higher education reform agenda in Norway is no exception (Bleiklie and Frølich, 2014).

Hence, in the Norwegian setting it is possible to identify at least three different policy ideas that match the European higher education reform agenda. First, there is a growing political agreement that, due to perceived stronger international competition for talent and resources, higher education institutions need to become more efficient and effective as producers of knowledge (Bleiklie, 2005). This perceived need also imply that higher education institutions should streamline their educational offerings, address inefficiencies and be more aware of the economic sustainability of the educational deliveries. In short, this idea - which often is associated with generic public management reform ideas (Bleiklie and Frølich, 2014) emphasise that more managerial control should be exercised over the design and organization of educational offerings (Ravinet, 2008). 
Second, in Europe it is also possible to see a shift in political attention away from the early focus on programme structures to an increased focus on student-centred learning, student skills and knowledge content (Vukasovic et al, 2015). For example, while the early years of the Bologna Process saw a strong focus on structural change related to the three plus two degree cycle and the establishment of the ECTS framework (Kehm et al, 2010), it is possible to argue that in later years much more political attention has been given to student qualifications, and how student learning can be enhanced (Elken, 2016).

Finally, it is also possible to identify a set of policy ideas that perceive higher education less as a public good and where market- and consumer needs should be prioritised more (Marginson, 2011). These ideas are quite diverse and include elements related both to privatization, competition and marketization but can be said to come together in the increasing political agreement that relevant stakeholders should be more involved or have a stronger say in how educational offerings are designed, organized and offered (Neave and Veiga, 2013).

\section{Policy ideas, perceptions and pointers related to practice}

Based on the policy agenda presented above, which are highly present and influential in the Norwegian context (Bleiklie, 2005; Karseth and Sivesind, 2010; Bleiklie and Frølich, 2014; Møthe et al., 2015), we can develop three analytical perspectives which can be expected to bear significance in the current change processes at study programme level: a managerial perspective, a disciplinary perspective, and a stakeholder perspective.

The managerial perspective emphasizes the important role of formal structures within universities and colleges and especially those that occupy the leadership positions within these structures (Cohen and March, 1974; Bleiklie, 2005; Irving, 2015). In this perspective, one can expect that educational leaders see their role as those expected to ensure effectiveness and efficiency, and that they consequently have been given more responsibility and more authority over the development and more say in key decisions regarding the programme (Bryman, 2007; Møthe et al, 2015). Given that leaders - at all levels - tend to be given at least some responsibility for obtaining results (Davies et al, 2001), one could expect that educational leaders would emphasize and prioritize challenges that might be related to key accountability issues within the sector, including drop-out, completion rates, economic sustainability, etc. (Caspersen and Frølich, 2014). One could also expect that their perceptions of what might boost student learning would reflect this. Hence, activities that stimulate reduced drop-out and increased student success in completion are likely priorities in this perspective. Furthermore, in a managerial perspective one could also expect that any designed change would emphasize the need for improved quality management and not least signals from key regulatory bodies, including external quality assurance (Caspersen and Frølich, 2015). As study programmes and educational offerings in the Norwegian funding system represent an important source of income for institutions, it can also be expected that educational leaders are exposed to strong accountability demands, that the institutional 
leadership is strongly engaged in quality issues, and study programmes are surrounded by a well-developed administrative support structure.

The disciplinary perspective focuses on the important role disciplines and professions have tended to have in embedding and shaping social and cultural activities within universities and colleges (Becher and Trowler, 2001). In this perspective, the perceptions of central quality challenges, what knowledge the programme should prioritise, and how the curriculum should be shaped, are seen through specific disciplinary and professional lenses (Blackmore, 2007; Young, 2013). As study programmes and educational offerings are very diverse regarding their content, their style of teaching, and in the ways students learn, one would expect to find considerable diversity as to what quality challenges educational leaders identify in their programmes (Biggs and Tang, 2011). Activities initiated to potentially boost the current focus on student learning could be expected to reflect this diversity. With respect to the ways in which changes are intended to take place, a disciplinary perspective would emphasize the ways in which knowledge is structured and organized within each discipline (Young, 2013), that disciplinary knowledge is reflected in the programme in a coherent way, and the involvement of the academic staff is a key driver for further improving the study programmes (Becher and Trowler, 2001; Solbrekke and Stensaker, 2016). However, as research also is highly valued, it can also be expected that challenges may arise as to how research and teaching can be interlinked and combined (Gibbs et al, 2009), including whether academic staff are committed to teaching, given that academic merits most often are accomplished through research, that academic staff have enough time for linking research to their teaching, and enough time for curriculum development.

In the stakeholder perspective one might argue that the focus will shift to an environmental and output-based orientation, including the relevance of study programmes and educational offerings for later employment of graduates. Hence, one could expect that improving links to the labour market, and development of programme features that emphasize the vocational skills and competences of the students are issues that could be seen as important quality challenges (Hovdhaugen and Wiers-Jenssen, 2015), and that these are high on the agenda for many educational leaders with respect to how student learning could be developed further (Irving, 2015). One could further expect that changes and developments in study programmes reflect signals from the outside regarding societal relevance. Furthermore, as competition between institutions for students has increased, one would expect that more attention is being put on enhancing student commitment as a way of building loyalty to the programme, and a strong focus on student recruitment and receiving a high number of applications. In a stakeholder perspective, one would also assume that feedback from students regarding programme and teaching and learning delivery and its content and relevance is perceived as very important and as a potential strong driver for change in study programmes (Spooren et al, 2013; Jungblut et al, 2015).

It is important to underline that these perspectives and the related assumptions made should be seen as analytical heuristics, and that the perspectives are not necessary mutually exclusive. Hence, they might be combined and be blurred into each other in a number of ways. For example, attention to student feedback and student concerns could be interpreted as 
a result of a more stakeholder approach to quality development while at the same time also reflecting a more disciplinary perspective on change where students are seen as an integrated part of the academic community. We will return to these issues in our discussion of the results.

\section{Data and methods}

The data are drawn from a unique survey among heads of study programmes at Norwegian higher education institutions conducted from December 2015 to March 2016. The survey covered all public higher education institutions with the exception of three small institutions of arts and design. A total of 33 institutions were contacted. Individuals with academic leadership responsibilities at the level of study programmes at universities, specialized universities and university colleges were invited to answer to the survey. To identify the heads of study programmes, study directors at the institutions were contacted and asked to provide the relevant names and e-mail addresses.

Through the institutional contacts we identified a target group of 1,010 people who were invited to answer the survey. After two reminders, 551 people answered, which yields a response rate of 54.6 percent. This response rate should in general be considered as satisfactory, but since the target group population could not be fully identified, it is not possible to make an exact calculation of representativeness. Since practically all institutions were included in the sample, and the responses reflect the institutional diversity in Norwegian higher education, one can still expect that the results present a representative picture.

The content of the survey addressed the leadership role of heads of study programmes, their areas of responsibility, co-operation with other actors within and external to higher education and aspects related to quality enhancement of the study programmes. There was no previous research-based information about the role of heads of study programmes to help the preparation of the survey instruments. However, the instruments were developed by a large project group with solid knowledge of the field and discussed with representative of higher education institutions. The questionnaire included several free-text responses, but information from these questions has not been analysed in the present paper. Data collection was conducted in line with national regulations for privacy protection and research ethics.

The data do not contain precise information about the sub-field to which the respective study programmes belong, only about the educational background of the respondents. This may still serve as a relatively valid indicator of major field of study.

The present survey among heads of study programmes is predominantly explorative due to limited previous knowledge of their tasks and responsibilities. Hence, there is a potential for further investigations, both with refined survey instruments and qualitative interviews. An identical survey has been conducted at a later stage in Denmark. The present paper does not include comparisons between the two countries, but the results were very similar with the Norwegian ones, strengthening our impression that the survey is both valid and reliable. 


\section{Results}

What are seen by heads of study programmes as the greatest quality challenges within study programmes in Norwegian higher education?

In the survey, heads of study programmes were asked to evaluate several aspects of the study programme by responding to a set of generic statements. In general, heads of study programmes have an overall positive view of their programme. As illustrated, most heads of study programmes think that their programme is academically coherent, that academic staff are both qualified and committed to teaching and that students are committed to their study programme. The programme leaders also think they are supported by the top institutional management and their own department. They are also relatively content with respect to student applications and the administrative and the ICT support related to the programmes. In general, the infrastructure surrounding the programmes seems to be assessed quite positively.

If we look more closely into the area of dissatisfaction, figure 1 discloses that the programme leaders are divided with respect to how they view the economic conditions surrounding their programme. While one third of the heads of study programmes disagree regarding the statement that the study programme has sound economic resources, another third of those responding assesses the economic conditions as satisfactory. Interestingly, almost a third of the programme leaders are neutral with respect to the statement. A clearer pattern is visible when focusing on other issues. For example, time for the academic staff to develop innovative and research-based study programmes seems to be lacking: half of the heads of study programmes disagree that there is sufficient time to develop innovative study programmes and 42 per cent disagree that there is sufficient time to develop research-based education. This dissatisfaction seems rather generic, as few differences regarding type of institutions were found regarding these aspects of the quality of the study programmes. The fact that both of these statements focus on time issues may suggest that the programme leaders may be referring to the potential dilemma academic staff face when trying to combine research and teaching. At least the data suggest that these problems are not related to capacity and qualifications. As seen in figure 1 the scientific capacity is sufficient and the programme leaders also perceived that they have a sufficient level of qualified staff to support their programme. 


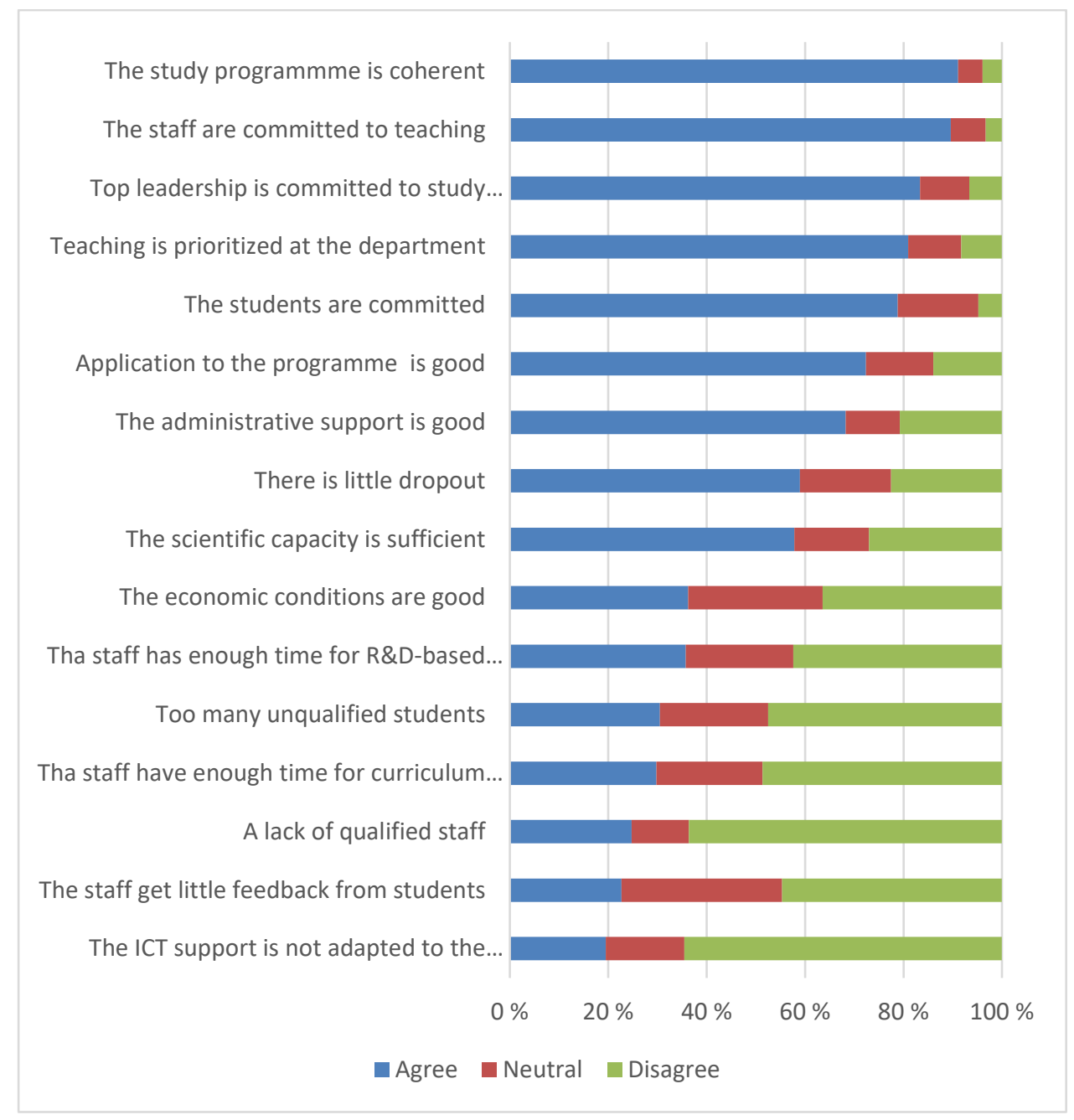

Figure 1 Heads of study programmes' responses to statements about the study programme

In the analysis, we have also controlled for potential differences between types of institutions and types of disciplines. However, few differences can be noted concerning institutional differences. For example, administrative support of study programmes at the universities seems to a larger extent to be perceived as better than at the university colleges. Academic staff at university colleges seem slightly more committed to teaching compared with academic staff at the universities. These findings are not very surprising given the traditional teaching orientation of university colleges, and that universities - which tend to be larger than the university colleges - may have a more developed administrative capacity.

If we look at disciplinary differences, we find that study programmes in technology are perceived as more coherent than study programmes in other fields. Study programmes in technology seem to have the highest number of applicants and the most committed students. Study programmes in the natural sciences and technology seem to have academic staff most committed to teaching compared with other fields. Moreover, heads of study programmes from the humanities and medicine are least satisfied with the economic situation of the study programme (more than 40 per cent disagree with the statement). Heads of study programmes 
in natural sciences are more satisfied with the economic resources of the programme -28 per cent disagree with the statement that the study programme has sound economic resources. These differences can be said to reflect well the existing funding situation in Norwegian higher education. Interestingly, humanities and medicine can be said to represent two extreme opposites regarding funding; while medicine receives most funding per student of all subject areas in the sector, humanities belong to the subject area receiving the least funding. The funding level seems, in other words, not to affect the assessment of the economic conditions.

\section{What are important measures taken to enhance the quality of study programmes?}

Heads of study programmes were also asked to indicate what measures they are currently implementing to enhance the quality of their programme. According to the heads of study programmes the most important quality measures taken are currently to strengthen coherence and to update the curriculum in line with state of the art within the field. These kinds of measures may be somewhat surprising as programme leaders seem quite satisfied with the coherence of their study programmes (see figure 1). Hence, it seems that the element most programme leaders are satisfied with is also the element most leaders prioritize in current improvement efforts.

Student-active learning initiatives are also very high on the agenda for further improvement. Along with the ambition to follow up students better, one could argue that many study programme leaders have a student focus related to their improvement activities. Given the fact that active learning has been strongly promoted through the recent Bologna statements, it seems that this priority is being reflected in current improvement processes in Norwegian higher education.

Of the remaining options, there are few that stand out in particular. Hence, it seems that study programme leaders are working to improve their programmes in several ways and using different measures. Given the public attention to new technology in the form of MOOCs and similar modes of delivery, it is perhaps somewhat surprising that the use of ICT is not higher up on the agenda for improvement. Along the same lines, it is also quite surprising that strengthening the contact with working life is not more prioritized. While around 40 per cent of the respondents indeed have initiated such contacts recently, one could have expected that this share had been even higher given the political attention on this topic, also within the Bologna Process.

There are relatively small differences between institutions. Hence, a quite similar pattern of improvement activities is visible in figure 2, although strengthening the coherence of the study programme and improvement of the teaching culture are considered more important measures for quality improvement at the universities compared with the university colleges. From the perspective of the university colleges, to increase the number of qualified staff and to strengthen research-based teaching are considered more important measures compared with the universities. Table 1 in the annex shows relatively small differences by discipline, but strengthening contact with the world of work is regarded most important in technology, 
updating the curriculum most important in medicine/health, and better use of ICT in teaching most important in natural sciences and medicine/health.

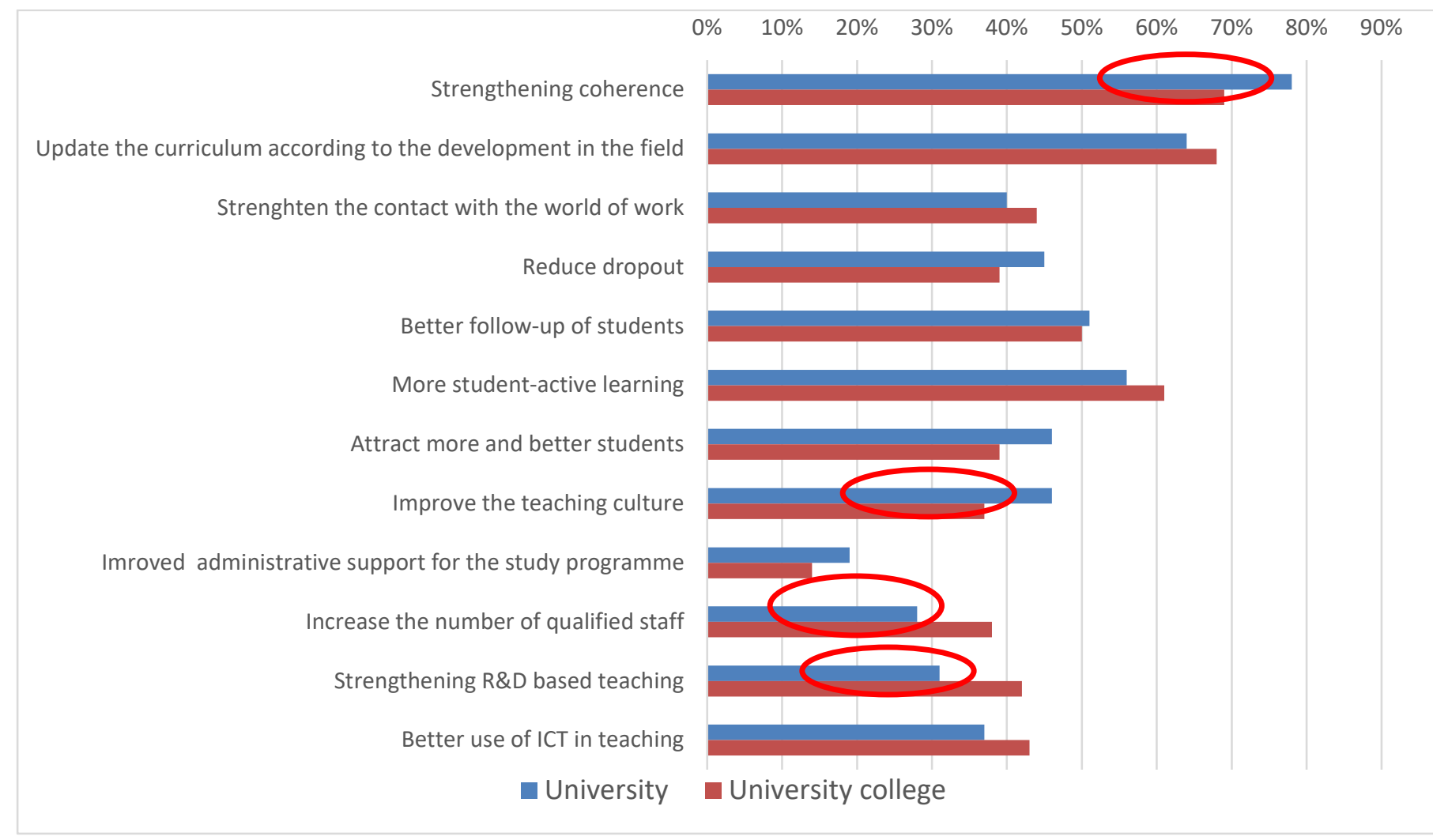

Figure 2 Statements about quality enhancement of the study programme

\section{In what ways are changes in study programmes taking place?}

In the survey, we also asked the programme leaders to identify important drivers and mechanisms behind the improvement initiatives taken (see figure 3). Here, quite distinct patterns come to the fore.

As shown in figure 3, most programme leaders think that the key driver behind recent changes in their study programmes relates to two factors: student evaluations and feedback from students in general, and knowledge development within the disciplinary and professional field to which they belong. The fact that knowledge development is identified as so important, matches earlier assessments made by the programme leaders underlining the need for strengthened coherence of their study programmes and the need to update the curriculum (see figure 2). The importance given to student feedback is also very noticeable, although it perhaps reflects the emphasis given with respect to introduce more active forms of learning, and to follow up students better (see figure 2).

What is more surprising is the fact that external factors such as feedback from the labour market and the world of work, and national quality assurance, are seen as only moderately 
important, and rated as the least important drivers of change. Again, this reflects perhaps the relative minor attention given to strengthening the contact with the labour market (see figure 2), and creates a picture of labour market needs as a not particularly important driver in Norwegian higher education. That national quality assurance also is seen as having moderate impact is unexpected as this mechanism has been heavily promoted through the Bologna Process over the years, not least related to the fact that Norwegian higher education has established a national accreditation system which potentially, if institutions and programmes are failing to meet national quality assurance standards, may have serious consequences. Hence, one could also have expected that this would have resulted in the establishment of internal quality assurance as an important underlying driver for programme change, but as figure 3 shows, internal quality assurance is not considered a particularly important driver for change.

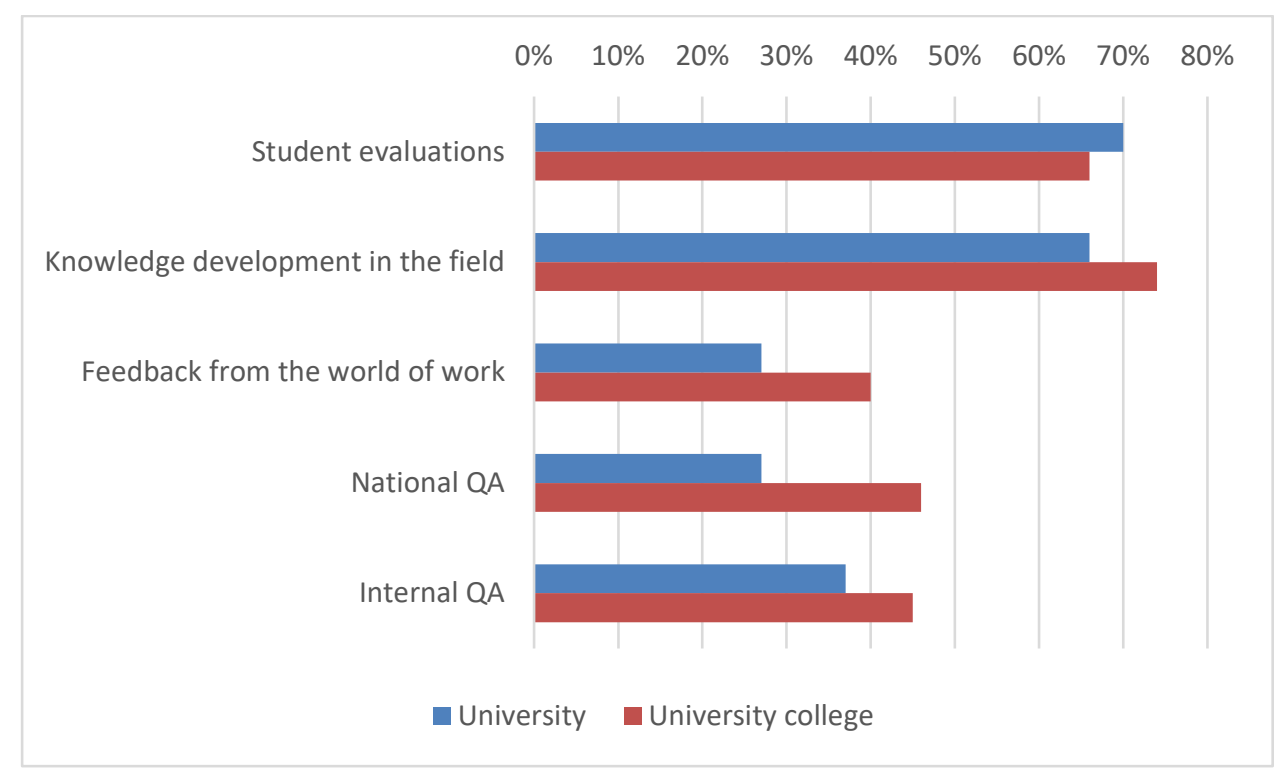

Figure 3 Statements about important factors for change

When we again control for institutional and disciplinary differences, it is especially the institutional differences that come to the fore. However, these differences are not very surprising as national quality assurance has been much more engaged in study programmes in university colleges than in universities, due to the fact that university colleges have many professional programmes closely interacting and collaborating with specific stakeholders in the labour market. Few disciplinary differences are noticeable, but feedback from the world of work is most important in technology (see table 2 in annex). 


\section{Discussion}

A key assumption in the current paper is that global policy ideas has created a multidimensional domestic reform agenda that can be interpreted in different ways, leading to a range of possible adaptations at study programme level. We started out in this paper by outlining three analytical perspectives on how to interpret current changes at study programme level; a managerial, a disciplinary and a stakeholder perspective. In general, we find that all three perspectives outlined have some explanatory potential, although we also see results that are more difficult to interpret in a clear cut way. Given that many politicians in Norway have launched strong claims about 'quality challenges' in Norwegian higher education (Frølich et al, 2016), we find it somewhat paradoxical that most heads of study programmes in Norwegian higher education assess the current state of affairs quite positively: a majority of leaders perceive their programme to be coherent, that the academic staff are devoted to teaching, and that the institutional leadership is committed to prioritizing educational quality. Hence, as such there appear to be relatively few quality challenges in Norwegian higher education, although one could, of course, question the validity of such claims coming from the providers of the educational offers. However, this rather positive image has also been supported by several of the recent national student surveys (Hovdhaugen and Wiers-Jenssen, 2015), suggesting that students also evaluate the quality of Norwegian higher education in quite positive terms. A recent survey among employers of graduates from higher education confirms the all-in-all positive picture seen from the perspective of employers (Støren et al, 2016). Still, some issues are seen as potentially challenging by the heads of study programmes: they do raise concerns about the economic situation with respect to their study programme and they do seem to be worried about the lack of time academic staff can devote to curriculum development and linking their teaching closer to research.

Based on the quite positive assessment of the current state of affairs, it is a paradox that a large majority of the heads of study programmes are engaged in strengthening the coherence of their study programme as their main priority, especially since they also report that the existing coherence of the programmes is quite good. Hence, they are in other words strongly engaged in improving something they already assess as holding high standards. If we are to speculate why this is so, several possible explanations come to the fore. First, we should acknowledge that coherence may be interpreted differently in different disciplinary and professional fields, and that the label hides different meanings and interests (Young, 2013). For example, coherence in professional educational programmes may be interpreted as coherence of the programme with regard to how well the programme prepares the students for the labour market, while in disciplinary programmes at the universities coherence might refer to internal coherence and the structure and content of the programme. Second, the need for coherence might also refer to the need to integrate the rapid knowledge development in disciplinary areas with educational offerings that strive to catch up.

If we return to our three initial perspectives outlined, it is possible to argue that the managerial perspective is not very dominant as an explanation as to how we should understand the development of study programmes in Norwegian higher education. Heads of study programmes seemingly do not perceive drop-out and completion rates as important 
challenges regarding the quality of study programmes, something one might have expected if their priorities were closely associated with effectiveness and efficiency issues. This lack of emphasis on efficiency issues is also quite surprising as economic sustainability seems to be an area of concern among the heads of study programmes, not least the political attention this issue has received at national level. As Norwegian study programmes are partly funded through the number of credits taken, one would expect that heads of study programmes would see low drop-out and high completion as a way to increase their overall credit performance, and consequentially, their overall funding. This is apparently not an issue high on the agenda for the head of study programmes. Given the quite profound interest in and build-up of national and institutional quality assurance systems, it is interesting that relatively few of the heads of study programmes see these systems and activities as important drivers for change in their study programmes. Hence, our findings suggest that, at least compared to some other countries (see e.g., Irving, 2015), the heads of study programmes play a modest role as a driver for change.

The disciplinary perspective seems to be more relevant as a way to understand and interpret how study programmes in Norway are currently changing. Based on our data, heads of study programmes point out that time to develop innovative and research-based study programmes is lacking, which suggest that this is seen as an important task among heads of study programmes, hinting also to a possible squeeze academic staff are experiencing in trying to balance their research and teaching duties. The significance of the disciplinary perspective is not least underlined by their emphasis on strengthening coherence and to update the curriculum in line with state of the art within the field. The knowledge development in the academic field is also regarded as a very important driver for change of study programmes. The fact that student-active forms of learning have a high priority may actually also be linked to the disciplinary perspective and to how disciplinary characteristics influence and are closely linked different teaching and learning modes (Biggs and Tang, 2011).

With respect to the relevance of the stakeholder perspective, our data can be said to be somewhat ambiguous. On the one side, heads of study programmes do not prioritize contact and close interactions with the world of work when they try to improve the quality of their study programmes. Furthermore, they neither see feedback from the world of work as a very important change driver. As many evaluations and assessments of quality in higher education currently have incorporated student satisfaction measures (Gibbs et al, 2009), the relative minor importance formal quality assurance seems to have as a driver for change can also be seen as an example of the lack of explanatory power of the stakeholder perspective. However, if one thinks of students as stakeholders of higher education, it is striking how important student evaluation and student feedback seem to be as a change driver in the study programmes. Of course, student evaluations can also be interpreted along the disciplinary perspective - as a way to strengthen the communication and academic interaction between student and staff in a more Humboldtian perspective (Kehm et al, 2010). Hence, the relatively huge weight given to student evaluations as a driver for change can be interpreted in very different ways. 


\section{Conclusions and reflections for policy and practice}

The current article positioned itself by pointing to the importance of global reform ideas as agenda setters for national reform. As global reform ideas have been and are translated into various national contexts, it is of interest to investigate and uncover the validity and substance of the rationale behind the reform ideas (the perceived 'quality challenges'), and how different expectations and reform ideas are influencing the study programme level.

Our study suggests that, at least with respect to Norwegian higher education, older reform ideas have effects that still affect the study programmes. For example, based on our data, one could argue that Norwegian study programmes are still struggling with the modularization and possible fragmentation of study programmes that were developed following the Bologna reform a decade ago. This is an issue recognizable from many other countries (Gibbs et al, 2009), and is visible through the work that continuously goes into building internal coherence and integration of study programmes offered in Norwegian study programmes. Hence, the programme structures that were built as part of the Bologna Process may still be challenging to handle for many heads of study programmes. This illustrate a problem with the global reform agenda as new ideas (student-centred learning, qualification frameworks, etc.) are launched into a sector still struggling to adjust to the reform ideas of the past.

At the same time, we can perhaps also argue that the 'control dimension' of related to the efficiency and effectiveness agenda have less impact in Norwegian higher education, at least in terms of how study programmes are managed. Quality assurance routines and activities play a relatively minor role as a driver for improvement, and the managerial focus on effectiveness and efficiency is rather downplayed. Following the national reform agendas emphasising the need to restructure institutional decision-making and strengthen the adaptiveness of higher education institutions (Bleiklie and Frølich, 2014), it is somewhat surprising to witness the quite strong disciplinary and academic grip on the development and priorities within the study programmes. In Norwegian higher education, it is difficult to identify a managerial revolution with respect to how study programmes are governed and led (see also Møthe et al, 2015). Still, as much attention currently seems to be linked to more student-centred forms of learning and more attention given to student satisfaction - issues that lately have been put high on the national reform agenda in Norway - one could argue that there is potential for more stakeholder influence over study programme development.

Our study has several possible implications for policy and practice. First, while the salience of disciplinary knowledge is underlined by our findings, the disciplinary perspective also discloses a familiar dilemma for the academic staff - how to balance research and teaching obligations. While the educational leaders in the current article report about an engaged academic staff committed to teaching, allocating time and energy to programme development seems to be a critical challenge for the academic staff. Steps need to be taken to address this dilemma. Bringing more attention to the links between research and teaching and how research-based teaching can be stimulated could be interesting alternatives to explore how to further integrate these two activities. Young`s (2013) ideas about how knowledge and 
knowledge concepts should be given more attention in curriculum development may here be relevant as such concepts provide a potential bridge between research and teaching.

Second, our data have also underlined the power of students as change agents in higher education. Feedback from students is apparently taken much more seriously than input from other external stakeholders such as quality assurance agencies and employers (see also Spooren et al, 2013). As we have discussed earlier, this development may be seen as a sign of a stronger consumer approach to higher education (Marginson, 2011), but as students is a diverse group, it should not be taken for granted that they look upon higher education merely as `consumption` or as obtaining credentials (Jungblut et al, 2015). Hence, if a more studentcentred agenda is matched with more traditional disciplinary characteristics and the traditional attention given to knowledge developments within specific fields, this coalition could become a very powerful driving force for future change in the curriculum and in the study programmes. 


\section{References}

Becher, T., and Trowler, P. (2001) Academic tribes and territories, Buckingham: Open University Press.

Biggs, J., and Tang, C. (2011) Teaching for quality learning, Berkshire: McGraw-Hill.

Blackmore, P. (2007) 'Disciplinary differences in academic leadership and management and its development: a significant factor?', Research in Post-Compulsory Education 12(12): 225-239.

Bleiklie, I. (2005) 'Academic leadership and emerging knowledge regimes' in I. Bleiklie and M. Henkel (eds). Governing knowledge. A study of continuity and change in higher education, Dordrecht: Springer, pp. 189-211.

Bleiklie, I., and Frølich, N. (2014) 'Styring og ledelse i politikk om høyere utdanning' in N. Frølich, E. Hovdhaugen, and L. I. Terum (eds). Kvalitet, kapasitet og relevans: Utviklingstrekk i norsk høyere utdanning, Oslo: Cappelen Akademisk, pp. 40-58.

Bryman, A. (2007) 'Effective leadership in higher education: a literature review', Studies in Higher Education 32(32): 693-710.

Caspersen, J., and Frølich, N. (2014) 'Læringsutbytte som styringsredskap for ledelsen i høyere utdanning' in N. Frølich, E. Hovdhaugen, and L. I. Terum (eds). Kvalitet, kapasitet og relevans: Utviklingstrekk i norsk høyere utdanning, Oslo: Cappelen Akademisk, pp. 58-80.

Caspersen, J., and Frølich, N. (2015) 'Managing learning outcomes: Leadership practices and old modes of new governance in higher education' in E. Reale and E. Primeri (eds). Universities in transition. Shifting institutional and organizational boundaries, Rotterdam: Sense, pp. 187-203.

Caspersen, J., Frølich, N. and Muller, J. (2017) 'Higher education learning outcomes ambiguity and change in higher education', European Journal of Education 52(1): 819.

Cohen, M. D., and March, J.D. (1974) Leadership and ambiguity: The American College President, New York: McGraw-Hill.

Davies, J., Hides, M.T., and Casey, S. (2001) ‘Leadership in higher education’ Total Quality Management 12(7): 1025-1030.

De Boer, H., File, J. Huisman, J., Seeber, M., Vukasovic, M. and Westerheijden, D. (2017) Policy analysis of structural reforms in higher education. Processes and outcomes. Cham: PalgraveMacmillan.

Elken, M. (2016) 'EU-on-demand': developing national qualifications frameworks in a multilevel context’, European Educational Research Journal 15(6): 628-643. 
Frølich, N., Gulbrandsen, M., Vabø, A., Wiers-Jenssen, J. and Aamodt, P.O. (2016) Kvalitet og samspill i universitets- og høgskolesektoren. Oslo, Norway: Nordic Institute for studies of Innovation, Research and Education. NIFU-report no. 2.

Gibbs, G., Knapper, C. and Piccinin, S., (eds) (2009) Departmental leadership of teaching in research-intensive universities. London: The Leadership Foundation for Higher Education.

Henkel, M. (2000) Academic identities and policy change in higher education. London: Jessica Kingsley Publishers.

Hovdhaugen, E., and Wiers-Jenssen, J. (2015) 'Hvordan vurderer studenter og nyutdannede utdanningens kvalitet og relevans?’, in N. Frølich (ed.). Hva skjer i universiteter og høyskoler?, Oslo: Universitetsforlaget, pp. 51-65.

Irving, K. (2015) 'Leading learning and teaching: an exploration of 'local' leadership in academic departments in the UK', Tertiary Education and Management 21(3): 186199.

Jungblut, J., Vukasovic, M., and Stensaker, B. (2015) 'Student perspectives on quality in higher education’ European Journal of Higher Education 5(2): 157-180.

Karseth, B. and Sivesind, K. (2010) 'Conceptualising curriculum knowledge within and beyond the national context’, European Journal of Education 45(1): 103-120.

Kehm, B. M., Huisman, J., and Stensaker, B. (2009) The European higher education area: Perspectives on a moving target, Rotterdam: Sense Publishers, pp.

Kehm, B. M., Michelsen, S. and Vabø, A. (2010) 'Towards the two-cycle degree structure: Bologna, reform and path dependency in German and Norwegian universities', Higher Education Policy 23(2): 227-245.

Marginson, S. (2011) 'Higher education and public good', Higher Education Quarterly 65(4): 411-433.

Maassen, P. and Stensaker, B. (2011) 'The knowledge triangle, European higher education policy logics and policy implications’, Higher Education, 61(6): 757-769.

Musselin, C. (2005) Change or continuity in higher education governance? In Bleiklie, I. \& Henkel, M. (eds.) Governing knowledge. Dordrecht: Springer.

Møthe, S., Ballangrud, B. and Stensaker, B. (2015) 'The values and visions of the professional department head: Not so different from the past?', The International Journal of Educational Management 29(3): 298-308.

Neave, G., and Veiga, A. (2013) 'The Bologna Process: inception, 'take up 'and familiarity', Higher education 66(1): 59-77. 
Ravinet, P. (2008) 'From Voluntary Participation to Monitored Coordination: why European countries feel increasingly bound by their commitment to the Bologna Process', European Journal of Education 43(3): 353-367.

Solbrekke, T.D. and Stensaker, B. (2016) 'Utdanningsledelse. Stimulering av et felles engasjement for studieprogrammene?’, Uniped 39(2): 144-157.

Spooren, P., Brocks, B., and Mortelmans, D. (2013) 'On the validity of student evaluation of teaching: The state of the art', Review of Educational Research 83(4): 598-642.

Støren, L. A., Carlsten, T. C., Reiling, R. B., Olsen, D. S. and Arnesen, C. (2016) Arbeidsgivers vurdering av nyansatte med høyere utdanning og fagskoleutdanning: Underveisrapport, første delrapport. Oslo, Norway: Nordic Institute for studies in Innovation, Research and Education. NIFU-arbeidsnotat no. 16.

Young, M. (2013) 'Overcoming the crisis in cirriculum theory: a knowledge-based approach', Journal of Curriculum Studies 45(2): 101-118.

Vukasovic, M., Jungblut, J., and Elken, M. (2015) 'Still the main show in town? Assessing political saliency of the Bologna Process across time and space', Studies in Higher Education (4):1-16. 